\title{
Biochemical, Microbiological and Sensory Quality of Underutilized Marine Gastropod Smoked Products from Chicoreus ramosus and Volegalea cochlidium
}

\author{
R. Emilin Renitta ${ }^{1, *}$, V. Deepak Samuel ${ }^{2}$, Jamila Patterson ${ }^{3}$, Prakash $\mathbf{P}^{4}$, Antony V Samrot ${ }^{5, *(D)}$ \\ 1 Department of Food Processing Technology, Karunya Institute of Technology and Sciences,Karunya Nagar 641114 , \\ Coimbatore, TamilNadu, India \\ 2 Conservation of Coastal and Marine Resources Division (CMR),National Centre for Sustainable Coastal Management \\ (NCSCM), Anna University Campus, Chennai 600025 \\ 3 Suganthi Devadason Marine Research Institute, Tuticorin, Tamil Nadu - 628 001, India \\ 4 Department of Biotechnology, School of Bio and Chemical Engineering, Sathyabama Institute of Science and Technology, \\ Jeppiar Nagar, Chennai, Tamil Nadu - 600 119, India \\ 5 School of Biosciences, Faculty of Medicine, Biosciences and Nursing, MAHSA University, Jalan SP2, Bandar Saujana \\ Putra, 42610, Jenjarom, Selangor, Malaysia \\ * Correspondence: emilinrenitta@karunya.edu (R.E.R.); antonysamrot@gmail.com (A.V.S.);
}

Scopus Author ID 36100751800

Received: 18.05.2020; Revised: 12.06.2020; Accepted: 13.06.2020; Published: 18.06.2020

\begin{abstract}
Gastropods are one of the important sea-foods rich in protein, glycogen, minerals, and lowfat content. The proximate composition such as protein, carbohydrate, and lipid content of the smoked meat of $C$. ramosus and $V$. cochlidium was $11.84,4.28,2.88$, and $8.96,4.74,3.04 \%$ respectively.The moisture content of both the smoked meat was gradually increased from $2.2-12.6 \%$ during storage at room temperature. The spoilage indicators such as Free Fatty Acids, TMA - N (Trimethylamine - Nitrogen), and TVB - N (Total Volatile Base- Nitrogen) values were found to be increased as storage time increased. The increasing TPC (Total Plate Count) and TFC (Total Fungal Count) and organoleptic characteristics were also increasing in both smoked meat during increased storage. This study indicated that the quality of $C$. ramosus and $V$. cochlidium smoked meat were found to be good and safe for human consumption even after 180 days of storage.
\end{abstract}

Keywords: Biochemical; microbiological; gastropod; smoked product and sensory quality.

(C) 2020 by the authors. This article is an open-access article distributed under the terms and conditions of the Creative Commons Attribution (CC BY) license (https://creativecommons.org/licenses/by/4.0/).

\section{Introduction}

Fish and fish products provide the world's prime source of high-quality protein is consumed as food all over the world. Most of the people rely on fish as their primary source of animal protein. Since fish and fishery products contains more than $60 \%$ of the total protein which is a vital component for adults that resulted in global increase in the consumption in rural areas[1]. Finfishes are also processed into various food and non-food products. Fish can also be used as a medicine, ground into vitamins or processed into cosmetics, lubricants, varnishes, soap, and margarine. Since sea-food is a perishable food, preservation techniques including freezing, chemical preservation, salting, and smoking have been utilized to improve the microbial safety and extend the shelf life of fish [2]. Eyo [3] stated that smoking involves heat application to remove water and inhibits bacterial and enzymatic action on fish. Effect of Brining and smoking on color and sensory perception are at least as important as the preservative effect due to the use of modern refrigeration systems [4]. Smoking is an effective 
method of fish processing that retains more protein value and removes the moisture content, which helps in preservation [5]. Smoking is often recommended as a masking agent for boar taint [6]. Smoking is one of the preservation methods, which has an effect on fish protein denaturation that resulted in physical and chemical structural changes and biological availability of protein [7]. Malarut and Vangnai [8] reported neem beechwood chips on different qualities of smoked sausages could be a low-cost alternative used in the meat industry. In developing countries, smoked fish is a major source of animal protein largely produced by hot-smoking in traditional kilns using fuelwood [9].

Next to finfishes and crustaceans gastropod is one of the important fishery resources in Tuticorin, South East Coast of India. In the Gulf of Mannar region, C. ramosus (Muricidae) and $V$. cochlidium (Melongenidae) are collected mainly through skin diving, by-catch from trawl, and modified gill nets [10]. Consumption of gastropods is restricted only to a small section of the fisherfolk. They are not aware of the nutritive value of this gastropod, and thus the meat is wasted in the shore itself [11]. Keeping this in mind, the present study was undertaken to develop smoked products from $C$. ramosus, and $V$. cochlidium based on consumer preference, and their quality was assessed for a period of 6 months during storage at room temperature.

\section{Materials and Methods}

\subsection{Preparation of smoked products from C. ramosus and V. cochlidium meat.}

The cleaned edible meat of $C$. ramosus and $V$. cochlidium was cut into thin round slices of about $1 \mathrm{~mm}$ thickness for smoking purposes. The meat slices were blanched separately in $5 \%$ boiling brine solution for 5 minutes. Then the meat was drained and spread on trays and air-dried for 20 minutes to facilitate smoke penetration. A conventional vertical type-Kiln was used for smoking the meat by burning sawdust. During smoking, samples were drawn every 15 minutes to observe the effect of smoking time on the quality of the meat. The good quality smoked meat (5\% brine, 60 minutes) was collected from the kiln and dried in electrical drier, and both meats were packed in separate polythene bags. The well-dried smoked products were fried for consumption. The stored smoked products were drawn bimonthly to analyze biochemical, microbiological, and organoleptic characteristics.

\subsection{Biochemical analysis.}

The proximate composition, such as protein, carbohydrate, and lipid content, was estimated by following the method of AOAC [12]. The biochemical quality such as $\mathrm{pH}$, moisture, FFA [13], TMA-N, and TVB-N were analyzed according to the Conway micro diffusion method of Beatty and Gibbons[14] during storage at ambient temperature.

\subsection{Microbiological analysis.}

Enumeration of Total Plate Count (TPC) and TFC (Total Fungal Count) were done as per the methods of the American Public Health Association [15]. Enumeration of pathogenic bacteria like E.coli, Vibrio spp, and Salmonella spp was carried out by following the methods of the US Food and Drug Administration [16]. 


\subsection{Sensory analysis.}

The sensory analysis of both smoked meat was carried out by frying the meat in edible oil and serving a taste panel of 6 to 8 members. The overall acceptability was determined using a hedonic scale of 1 to 9 [17]. Products with scores above 6 were considered as good and below 5 as poor and unacceptable.

\subsection{Statistical analysis.}

All the analyses were done with three samples, and the results are illustrated as mean \pm standard deviation.

\section{Results and Discussion}

The protein, carbohydrate, and lipid content of the smoked products of $C$. ramosus and $V$. cochlidium were $11.84,4.28,2.88$, and $8.96,4.74,3.04$, respectively (Table 1a.). The smoked meat of $C$. ramosus and $V$. cochlidium had a good level of protein, carbohydrate content, and low lipid content. Shanthini and Patterson [18] have reported similar high protein and low lipid content in the smoked meat of Pleuroploca trapezium. Another research study stated that the different smoking process significantly decreased the lipid content of fish [19]. Nunoo et al. [20] found that there was a low-fat content in smoked fish, which is similar to our study results.

Table 1a. Proximate composition of $C$. ramosus and V. cochlidium smoked gastropods.

\begin{tabular}{lll}
\hline Parameters & C. ramosus & V. cochlidium \\
\hline Protein (\%) & $11.84 \pm 1$ & $8.96 \pm 0.3$ \\
Carbohydrate (\%) & $4.28 \pm 0.9$ & $4.74 \pm 0.5$ \\
Lipid (\%) & $2.88 \pm 0.5$ & $3.04 \pm 0.3$ \\
\hline
\end{tabular}

The biochemical and microbiological characteristics of $C$. ramosus and $V$. cochlidium smoked meat are presented in Table $1 \mathrm{~b}$ and $1 \mathrm{c}$. The $\mathrm{pH}$ levels of both the smoked meat were slightly acidic and ranged from 6.58 to 5.87 during the storage at ambient temperature. Similar $\mathrm{pH}$ ranging from 6.1 to 6.9 was observed by Kickzorowska et al. [21] in smoked fish. The level of $\mathrm{pH}$ showed a decreasing trend during storage. The $\mathrm{pH}$ level is the main quality indicator for foods. The level of $\mathrm{pH}$ in both the products showed a decreasing trend during storage. The acidic $\mathrm{pH}$ of both smoked meat during storage may be due to phenolic/acidic constituents deposited on the gastropod meat during smoking.

The changes in the moisture level of smoked meat of $C$. ramosus and $V$. cochlidium during storage at ambient temperature are presented in Table $1 \mathrm{~b}$ and $1 \mathrm{c}$. The percentage of moisture content was $2.7 \pm 0.01$ and $2.28 \pm 0.01$, respectively. It gradually increased during storage and reached a maximum level of $12.26 \pm 0.02$ and $8.26 \pm 0.01$, respectively.

Table 1b. Biochemical and microbiological characteristics of $C$. ramosus smoked product during storage.

\begin{tabular}{lllll}
\hline Parameters & Initial & $\begin{array}{l}\mathbf{6 0}^{\text {th }} \\
\text { Day }\end{array}$ & $\begin{array}{l}\mathbf{1 2 0}^{\text {th }} \\
\text { day }\end{array}$ & $\begin{array}{l}\mathbf{1 8 0}^{\text {th }} \\
\text { day }\end{array}$ \\
\hline $\mathrm{pH}$ & $6.58 \pm 0.01$ & $6.46 \pm 0.01$ & $6.14 \pm 0.01$ & $5.87 \pm 0.02$ \\
Moisture (\%) & $2.7 \pm 0.01$ & $4.89 \pm 0.005$ & $6.94 \pm 0.01$ & $12.26 \pm 0.02$ \\
FFA (\% oleic acid) & $0.026 \pm 0.001$ & $0.056 \pm 0.001$ & $0.092 \pm 0.001$ & $0.136 \pm 0.001$ \\
TPC (x 10 $\mathrm{CFU} / \mathrm{g})$ & $46 \pm 1.15$ & $63 \pm 1.15$ & $88 \pm 1.5$ & $104 \pm 1.15$ \\
TFC $\left(\mathrm{x} \mathrm{10} 10^{2} \mathrm{CFU} / \mathrm{g}\right)$ & NIL & $0.47 \pm 1.15$ & $0.47 \pm 1.15$ & $0.60 \pm 1.15$ \\
\hline
\end{tabular}


Table 1c. Biochemical and microbiological characteristics of $V$. cochlidium smoked product during storage.

\begin{tabular}{lllll}
\hline \multicolumn{1}{c}{ Parameters } & \multicolumn{1}{c}{ Initial } & \multicolumn{1}{c}{$\begin{array}{c}\mathbf{6 0}^{\text {th }} \\
\text { Day }\end{array}$} & \multicolumn{1}{c}{$\begin{array}{c}\mathbf{1 2 0}^{\text {th }} \\
\text { day }\end{array}$} & \multicolumn{1}{c}{$\begin{array}{c}\mathbf{1 8 0}^{\text {th }} \\
\text { day }\end{array}$} \\
\hline pH & $6.51 \pm 0.005$ & $6.47 \pm 0.01$ & $6.2 \pm 0.01$ & $5.9 \pm 0.01$ \\
Moisture (\%) & $2.28 \pm 0.01$ & $4.37 \pm 0.01$ & $7.5 \pm 0.01$ & $8.26 \pm 0.01$ \\
FFA (\% oleic acid) & $0.023 \pm 0.001$ & $0.046 \pm 0.001$ & $0.089 \pm 0.001$ & $0.128 \pm 0.001$ \\
TPC (x 10 CFU/g) & $42 \pm 1.15$ & $56 \pm 0.5$ & $79 \pm 0.5$ & $94 \pm 0.57$ \\
TFC (x 10 $10^{2}$ CFU/g) & NIL & $0.477 \pm 1.15$ & $0.778 \pm 1.15$ & $0.778 \pm 0.5$ \\
\hline
\end{tabular}

A significant difference was noticed with the increasing storage period of both the smoked meat. Moisture levels play an important role in the spoilage. The moisture content of the smoked meats gradually increased during the storage period of 180 days. The increase in moisture level may have influence on microbial content. The moisture level of both smoked gastropod meat was found to be less than $20 \%$, which was in agreement with the work of Adebowale et al. [22].

The changes in Free Fatty Acid (FFA) content (\% oleic acid) during storage at ambient temperature are given in Table $1 \mathrm{~b}$ and $1 \mathrm{c}$. The FFA content of $V$. cochlidium and $C$. ramosus smoked meat were increased slowly after 180 days of storage. The values of FFA in both the products were low in the initial period but showed an increasing trend during the storage period. The increase in FFA content at the end of the storage period showed that there might have been a certain degree of lipid hydrolysis. Similar results were noted in marine gastropod pickle developed from $C$. ramosus [23]. Another study suggested that the phytonutrient supplementation may reduce accumulation of primary and secondary lipid oxidation products during storage in both muscle and adipose tissue of pork [24].

The Trimethylamine Nitrogen (TMA-N) and Total Volatile Base Nitrogen (TVB-N) of $C$. ramosus and $V$. cochlidium smoked meat are shown in Fig. 1 and 2. The TMA-N and TVB$\mathrm{N}$ levels of both the smoked meat increased. The TMA $-\mathrm{N}$ and TVB $-\mathrm{N}$ (mg / $100 \mathrm{~g}$ ) content of both the smoked meat was more significant during storage. The increase of TMA - N values of both smoked meat may be due to the increase in moisture content during the storage. TMA$\mathrm{N}$ has been found to be a useful index of spoilage and parameter for freshness assessment of sea-food. TMA - N is produced as a result of bacterial reduction of TMAO [14]. In both smoked meats it was found to be lesser than $15 \mathrm{mg} / 100 \mathrm{~g}$, the limit of acceptability, and showed an increasing trend during the storage period. The increase of TMA - N values in both smoked meat may be due to the increase in moisture content during the storage.

The increase in TVB-N during the storage period may be due to microbial activity, moisture, and storage temperature, which is in accordance with Kumar et al. [25].The TVB $\mathrm{N}$ values of both the smoked meat were well within the acceptability limit of $30 \mathrm{mg} 100 \mathrm{~g}^{-1}$ [26]. The pattern of increase of TVB - N was also similar, observed in smoked fishes, and did not affect the organoleptic qualities [27]. Daramola et al. [28] reported a similar increasing trend of TVB-N value with storage time in the hot smoked Clarias gariepinus sample. As storage period increases the total volatile base increases in brine smoked fish which is higher (24.12 \pm 0.53$)$ than the pepper coated smoked fish ( 21.61 \pm 0.56$)$ [29]

Spoilage by microorganisms is a major part of the quality deterioration of smoked fish during storage [30]. Detection of food contamination by bacteria is a major concern in the food sector [31]. The Total plate counts of $C$. ramosus and $V$. cochlidium smoked meat during storage at ambient temperature are given in Table $1 \mathrm{~b}$ and 1c. TPC and TFC of both meats were found to be increasing as the storage period increased (Table 1a and 1b). These levels were well within the permissible level of fishery products, and it may be due to the antibacterial action of the chemical compounds. Patience et al. [32] stated that there was a significant 
difference in the mycoflora counts of smoked fish from different markets in Nigeria. Similar results were observed by Likongwe et al.[33] with respect to total viable bacterial counts of smoked catfish $\left(5.6 \times 10^{6} \mathrm{CFU} / \mathrm{g}, 1.9 \times 10^{6} \mathrm{CFU} / \mathrm{g}\right.$, respectively) processed in traditional and improved smoking Kiln. Pathogenic bacteria like E. coli, salmonella, and vibrio were not enumerated in both the products throughout the storage period. Identical results were reported by Ratsimba et al. [34] in kitoza, a smoked meat product of Madagascar. There was no Salmonella, Listeria monocytogenes, and Staphylococcus aureus was found in smoke-dried fish developed in Benin[35]. A higher count of Yeast and Mold spp. were isolated in smoked Tenualosa ilisha, Oreochromis mossambicus, Pangasius hypophthalmus during storage [36]. Similarly, the TPC among catfish steaks within each treatment or control group tended to increase and reached approximately $3 \log \mathrm{CFU} \mathrm{g}{ }^{-1}$ noticed at 6 weeks storage period [37]. As the storage period increased, products may absorb moisture from the environment, which favors the growth of microorganisms [38]. To improve the quality of smoked fish, best practices could be developed to avoid mostly the fungal contaminations [39]. Similar fungal contaminants were observed in Smoked catfish and reported by Chukwuemeka et al. [40].

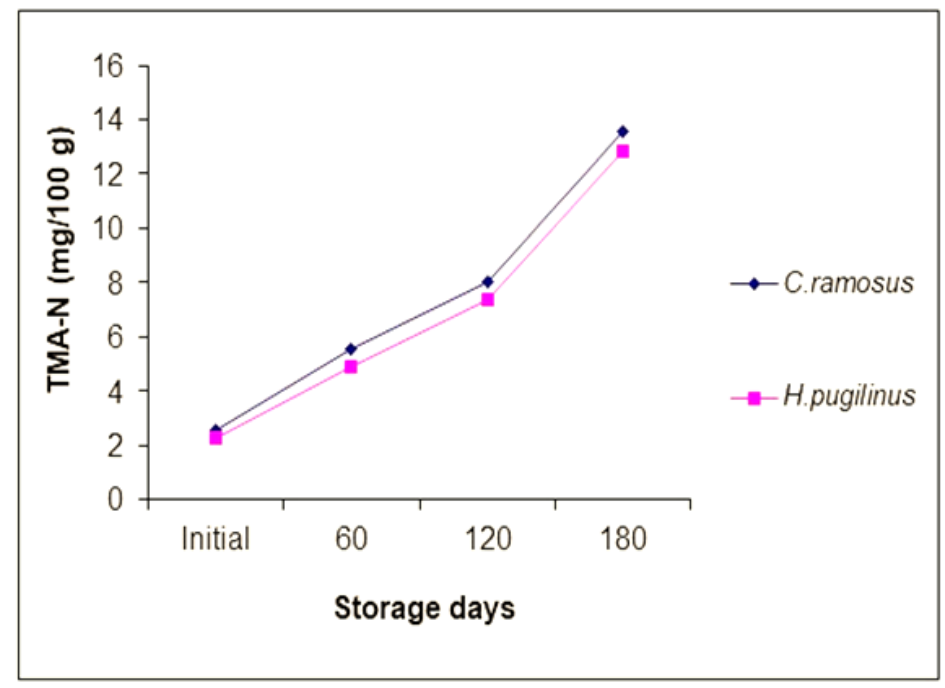

Figure 1. Changes in TMA - $\mathrm{N}$ level of $C$. ramosus and $V$. cochlidium smoked meat stored at ambient temperature.

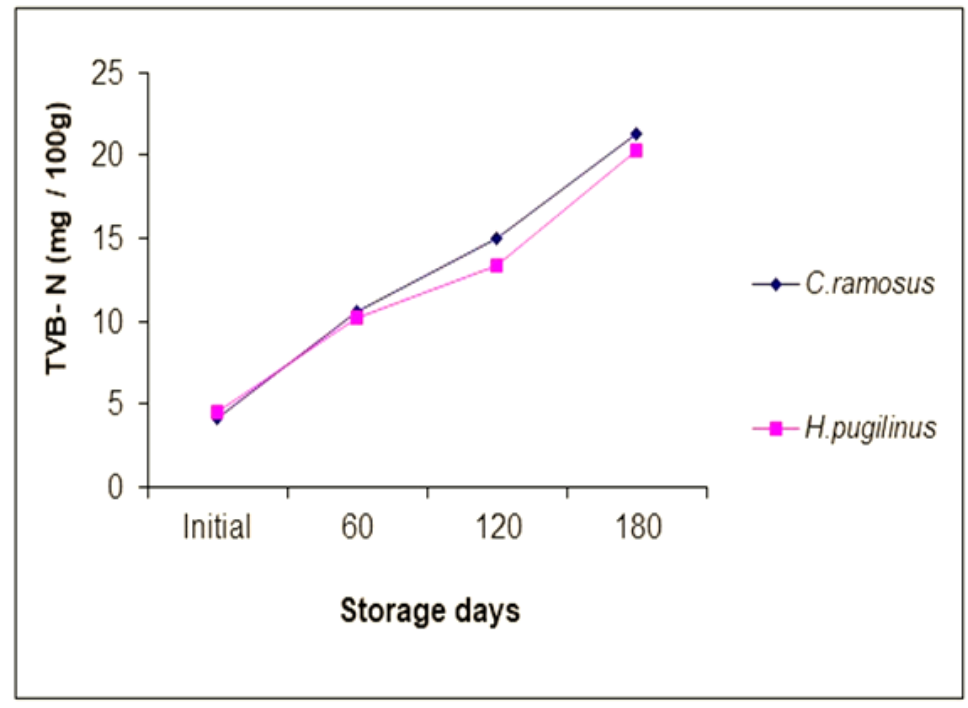

Figure 2. Changes in TVB - N level of C. ramosus and $V$. cochlidium smoked meat stored at ambient temperature. 
The organoleptic characteristics of smoked meat of $C$. ramosus and $V$. cochlidium during storage at ambient temperature are given in Table 2a and $2 \mathrm{~b}$. The sensory scores of $C$. ramosus and $V$. cochlidium remained within the acceptability limit throughout the storage period. The overall acceptability of both smoked meat ranged from $8.8 \pm 0.05-7.8 \pm 0.005$ during the storage period. The organoleptic characters of both the smoked meat were significant during increased storage. In C. ramosus, the color of the smoked meat was found to be not good. The sensory evaluation of both the products at ambient temperature resulted in good sensory qualities throughout the storage period. Quality appreciation is mainly based on sensory attributes such as texture, color, taste, and odor for smoke-dried fishes [41]. There was a decreasing trend of odor and texture of smoked Clarias gariepinus, which is identical to our results [42]. Sowumi [43] stated that smoked fish is highly desirable because of its enhanced flavor and texture in fish due to smoking that acts upon microbiological, enzymatic and chemical deteriorative alteration In the present study, the sensory scores for both smoked meats showed a gradual decrease during 180 days of storage, but within the acceptability limit, and this may be due to the changes in biochemical and microbiological parameters. For good consumer acceptance, the perceivable sensory attributes are appearance, color, taste, and texture, and the synthesized judgments of all quality attributes provide the overall quality of the product [44]. Shikoki and Aminigo [45] reported that all the sensory parameters remained acceptable during the entire storage period of smoke-dried fish. Osibona et al. [46] observed that the storage containers play a vital role in the preservation of smoke-dried fish, which recommended the use of airtight storage containers for smoked fish.

Table 2a. Organoleptic characteristics of smoked product of $C$. ramosus during storage.

\begin{tabular}{lllll}
\hline $\begin{array}{l}\text { Organoleptic } \\
\text { characters }\end{array}$ & Initial & $\begin{array}{l}\mathbf{6 0}^{\text {th }} \\
\text { day }\end{array}$ & $\begin{array}{l}\mathbf{1 2 0}^{\text {th }} \\
\text { Day }\end{array}$ & $\begin{array}{l}\mathbf{1 8 0}^{\text {th }} \\
\text { day }\end{array}$ \\
\hline Appearance & $8.7 \pm 0.1$ & $8.5 \pm 0.1$ & $8.25 \pm 0.01$ & $8.0 \pm 0.01$ \\
Colour & $8.5 \pm 0.1$ & $8.5 \pm 0.1$ & $8.2 \pm 0.01$ & $7.85 \pm 0.005$ \\
Odour & $8.6 \pm 0.05$ & $8.2 \pm 0.01$ & $8.2 \pm 0.01$ & $8.0 \pm 0.005$ \\
Taste & $8.5 \pm 0.1$ & $8.5 \pm 0.1$ & $8.0 \pm 0.06$ & $7.5 \pm 0.01$ \\
Texture & $8.2 \pm 0.01$ & $8.0 \pm 005$ & $8.0 \pm 0.02$ & $7.85 \pm 0.005$ \\
Flavour & $8.8 \pm 0.05$ & $8.5 \pm 0.1$ & $8.5 \pm 0.05$ & $8.0 \pm 0.005$ \\
Overall & $8.8 \pm 0.05$ & $8.5 \pm 0.1$ & $8.2 \pm 0.1$ & $8.0 \pm 0.01$ \\
acceptability & & & & \\
\hline
\end{tabular}

Table 2b. Organoleptic characteristics of smoked product of $V$. cochlidium during storage.

\begin{tabular}{lcccc}
\hline $\begin{array}{l}\text { Organoleptic } \\
\text { characters }\end{array}$ & Initial & $\begin{array}{c}\text { 60th } \\
\text { day }\end{array}$ & $\begin{array}{c}\text { 120th } \\
\text { day }\end{array}$ & $\begin{array}{c}\text { 180th } \\
\text { day }\end{array}$ \\
\hline Appearance & $8.5 \pm 0.1$ & $8.2 \pm 0.005$ & $8.0 \pm 0.005$ & $8.0 \pm 0.02$ \\
Colour & $8.5 \pm 0.05$ & $8.0 \pm 0.01$ & $8.0 \pm 0.06$ & $7.6 \pm 0.1$ \\
Odour & $8.6 \pm 0.005$ & $8.0 \pm 0.02$ & $7.8 \pm 0.005$ & $7.6 \pm 0.05$ \\
Taste & $8.2 \pm 0.01$ & $8.4 \pm 0.05$ & $7.5 \pm 0.005$ & $7.8 \pm 0.01$ \\
Texture & $8.8 \pm 0.05$ & $8.0 \pm 0.06$ & $7.65 \pm 0.01$ & $7.5 \pm 0.1$ \\
Flavour & $8.7 \pm 0.05$ & $8.4 \pm 0.05$ & $8.0 \pm 0.005$ & $8.0 \pm 0.005$ \\
Overall & $8.8 \pm 0.05$ & $8.5 \pm 0.05$ & $8.0 \pm 0.02$ & $7.85 \pm 0.005$ \\
acceptability & & & & \\
\hline
\end{tabular}

\section{Conclusions}

Value addition increases the appealing appearance to the gastropod meat among the consumers. It thereby increases its utilization in the domestic market. The present study result revealed that $C$. ramosus and $V$. cochlidium smoked meat are good and safe for human consumption even till 180 days without any spoilage. 


\section{Funding}

This research received no external funding.

\section{Acknowledgments}

This research has no acknowledgment.

\section{Conflicts of Interest}

The authors declare no conflict of interest.

\section{References}

1. Otolowo, D.T.; Olapade, A.A. Influence of Processing Parameters on Microbial Load, Sensory Acceptability, and Mineral Contents of Dehydrated Catfish (Clariasgariepinus). J. Culinary Sci. Technol. 2018, 16(3), 209-223, https://doi.org/10.1080/15428052.2017.1363106.

2. Nickelson, R.I.; McCarthy, S.; Finne, G. Fish, crustaceans and precooked sea-foods. In: Compendium of methods for the Microbiological Examination of Foods. eds by Downes, E.P.; Ito, K.) fourth edn. American Public Health Association, Washington, DC. 2001; pp. 497-505,

3. Eyo, A.A. Fish processing technology in the tropics. University of Ibadan Press. 2000; pp. 165-168.

4. Yanar, Y.; Çelik, M.; Akamca, E. Effects of brine concentration on shelf-life of hot-smoked tilapia (Oreochromis niloticus) stored at $4^{\circ} \mathrm{C}$. Food Chemistry 2006, 97, 244-247, https://doi.org/10.1016/j.foodchem.2005.03.043

5. Akinwumi, F. Effects of Smoking and Freezing on the Nutritive Value of African Mud Catfish, ClariasgariepinusBurchell, 1822. The Journal of Agricultural Science 2014, 6, 143, https://doi.org/10.5539/jas.v6n11p143.

6. Aaslyng, M. D.; Granly, K.A.The use of smoke as a strategy for masking boar taint in sausages and bacon. Food research international, 2018, 108, 387-395, https://doi.org/10.1016/j.foodres.2018.03.069.

7. Abraha, B.; Admassu, H.; Mahmud, A. Effect of processing methods on nutritional and physico-chemical composition of fish: a review. MOJ Food Process Technol. 2018, 6(4), 376-382, https://doi.org/10.15406/mojfpt.2018.06.00191.

8. Malarut, J.; Vangnai, K. Influence of wood types on quality and carcinogenic polycyclic aromatic hydrocarbons (PAHs) of smoked sausages. Food Control. 2018, 85, 98-106 https://doi.org/10.1016/j.foodcont.2017.09.020.

9. Bomfeh, K.; Jacxsens, L.; Amoa-Awua, W.K. Reducing polycyclic aromatic hydrocarbon contamination in smoked fish in the Global South: a case study of an improved kiln in Ghana. J Sci Food Agric. 2019, 99(12), 5417-5423, https://doi.org/10.1002/jsfa.9802.

10. Patterson, J., Edward, J.K.P., Samuel, V., Wilhelmsson, D., Tamelander, J., Linden, O. The role of alternate livelihoods and awareness creation in coral reef conservation in the Gulf of Mannar, South eastern India. In: Ten Years after Bleaching: Facing the Consequences of Climate Change in the Indian Ocean. eds. by Obura, D.O.; Tamelander, J.; Linden, O) CORDIO Status Report 2008, Coastal Oceans Research and Development in the Indian Ocean/Sida-SAREC,Mombasa, Kenya, 2008; pp. 387-395.

11. Renitta, R.E.; Gnanambal, K.M.E.; Patterson, J. Development of chutney powder from spider conch, Lambis lambis(Linne, 1758). Asian Fisheries Science2006, 19, 309-317.

12. AOACOfficial Methods of Analysis. $15^{\text {th }}$ Edn., Association of Official Analytical Chemists, Washington DC, USA, 1990, pp 200-210.

13. Ke, P.J.; Reyier, C.W.;Ackman, R.G. News Series Circular, Fisheries and Oceans.I Canada, Halifax1976,61.

14. Beatty, S.A.; Gibbons, N.E. The Measurement of Spoilage in Fish. Journal of the Biological Board of Canada 1937, 3, 77-91, https://doi.org/10.1139/f37-007.

15. Vanderzant, C.; Splittstoesser, D.F. Compendium of Methods for the Microbiological Examination of Foods. $3^{\text {rd }}$ Edn, American Public Health Association, Washington, DC,1992.

16. Food and Drug Administration. Bacteriological Analytical Manuals. $8^{\text {th }}$ Edn. AOAC International, Gaithersburg, MD,1998.

17. Amerine, M.A.; Pangborn, R.M.; Roessler, E.B. Principles of Sensory Evaluation of Food. New York, Academic Press, 1965; pp. 46-65.

18. Shanthini, C.F.; Patterson, J. Smoke curing of Pleuroploca trapezium meat (Gastropod: Fasciolariidae). Phuket Marine Biological Centre Special Publication2001,25, 221-224.

19. Tiwo, C.T.; Tchoumbougnang, F.; Nganou, E.; Kumar, P.; Nayak, B. Effect of different smoking processes on the nutritional and polycyclic aromatic hydrocarbons composition of smoked Clarias 
$\begin{array}{lllll}\text { gariepinus } \text { and Cyprinus } & \text { carpio. Food } \quad \text { Sci } \quad \text { Nutr. } & \mathbf{2 0 1 9}, \quad 7(7), \quad 2412-2418,\end{array}$ https://doi.org/10.1002/fsn3.1107.

20. Nunoo, F.K.E.; Tornyeviadzi, E.; Asamoah, E.K.; et al. Effect of two fish smoking ovens on the nutritional composition and PAH content of smoked fish. $J$ pub health catalog. 2018, 1(1), 5-10.

21. Kiczorowska, B.; Samolińska, W; Grela, E. R.; Bik-Małodzińska, M. Nutrient and Mineral Profile of Chosen Fresh and Smoked Fish. Nutrients, 2019, 11(7), 1448, https://doi.org/10.3390/nu11071448.

22. Adebowale,B A.;Dongo, L N.;Jayeola, C O.;Orisajo, S B. Comparative quality assessment of fish (C.gariepinus) smoked with cocoa pod husk and three other different smoking materials.J. Food Technol.2008, 6, 5-8.

23. Renitta, R.E.; Patterson,J. Quality and shelf life assessment of underutilized marine gastropod pickle.Journal of Food Processing and Preservation. 2013,32, 589-593, https://doi.org/10.1111/j.17454549.2012.00679.x

24. Vlahova-Vangelova, D.; Balev, D.; Ivanova, S.; Nakev, J.; Nikolova, T.; Dragoev, S.; Gerrard, D. Improving the oxidative stability of pork by antioxidant type phytonutrients. Biointerface Research in Applied Chemistry 2020, 10(3), 5624 - 5633, https://doi.org/10.33263/BRIAC103.624633.

25. Kumar, A.; Singh, P.;Danish,M. Changes in proximate,biochemical and Microbiological characteristics of dried Labeo gonius fillets during storage at room temperature.African J Biotechnol. 2013,12,29973005.

26. Tanikawa, E. Studies on measuring freshness of fish and shellfish meat. Journal of Social Industrial Fisheries(Japan) 1935, 3, 267-296.

27. Lilabati, H. Vishwanath, W. Biochemical nutritional and microbiological quality of six species of smoked fishes from Manipur. Fishery Technology 2000, 37, 89-94.

28. Daramola, J.A.; Kester, C.T.; Allo, O.O. Biochemical evaluation of hot smoked African cat fish(C.gariepinus) sampled from Sango and Ota market Ogun state. ThePacific journal of Science and Technology 2013, 14, 380-386.

29. Fakunle, J.O.; Effiong, B.N.; Ibanga, U.I.; Adebayo, E. Quality Assessment of Smoked Dried Fish Packed In Sealed Transparent Polythene Nylon. Journal of Agriculture and Veterinary Science 2018, 11(5), 39-43, https://doi.org/10.9790/2380-1105013943.

30. Salaudeen, M.M.; Osibona, A.O. Impact of smoking techniques and storage conditions on microbial safety and stability of catfish (Clarias gariepinus). Ife Journal of Science 2018, 20(1) ,345-353.

31. Biswal, P.; Pal, A.; Das, A.P. Biosensor for detection of bacteria with probiotic potential and food pathogens. Letters in Applied Nanobioscience $\mathbf{2 0 2 0}, \quad 9(1), \quad 800-807$, https://doi.org/10.33263/LIANBS91.800807.

32. Patience, A.N.; Emmanuel ,C.; Ikechukwu. Mycoflora and Public Health Risks of Smoked Fish Sold in Port Harcourt Markets, Nigeria. American Journal of Microbiological Research 2019, 7(3),78-82.

33. Likongwe, M.C.; Kasapila, W.; Katundu,M.; Mpeketula, P.Microbiological quality of traditional and improved kiln smoked catfish (Clarias gariepinus; Pisces; Clariidae) in Lake Chilwa. Basin Food Science and Nutrition 2019, 7(1), 281-286, https://doi.org/10.1002/fsn3.885.

34. Ratsimba, A.; Rakoto, D.; Jeannoda, V. Physicochemical and microbiological characteristics of kitoza, a traditional salted/dried/smoked meat product of Madagascar. Food Sci Nutr. 2019, 7(8), 2666-2673.

35. Anihouvi, D.G.H.; Kpoclou, Y.E.; Massih, A. M. Microbiological characteristics of smoked and smokeddried fish processed in Benin. Food Sci Nutr. 2019, 7(5), 1821-1827.

36. Dutta, M.; Majumdar, PR.; Islam, R.U.; Saha, D. Bacterial and Fungal Population Assessment in Smoked Fish during Storage Period. J Food Microbiol Saf Hyg 2018 3, 127, https://doi.org/10.4172/24762059.1000127.

37. Antoniada-Silva, L.V.; Bankston-Jr, J.M.K.; Beilei, J.D.Effect of preservatives on microbial safety and quality of smoked blue catfish (Ictalurus furcatus) steaks during room-temperature storage. Food Microbiology 2008, 25, 958-963, https://doi.org/10.1016/j.fm.2008.07.001.

38. Eyo, A.A. Fish processing technology in the tropics. University of IllorinPress, 2006.

39. Akwuobu, C.; Antiev, W.; Ofukwu, R. Fungal Contaminants of Smoke-Dried Fish Sold in Open Markets in Makurdi, Benue State, North-Central Nigeria. Food and Nutrition Sciences 2019, 10, 290-297.

40. Chukwuemeka I.C.; David, A.C.; Ogwuegbu, H.O.; Akwari, D.K. Fungal profile associated with spoilage of smoked catfish sold in Aba, Abia State, Nigeria. GSC Biological and Pharmaceutical Sciences, 2020, 10(3), 110-117, https://doi.org/10.30574/gscbps.2020.10.3.0046.

41. Assogba, M.F.; Anihouvi, D.G.H.; Afe, O.H.I.; Kpoclou, YE.; Mahillon,J .; Scippo, M.; Hounhouigan, D.J.; Anihouvi, V.B.; Yildiz, F. Processing methods, preservation practices and quality attributes of smoked and smoked-dried fishes consumed in Benin. Cogent Food \& Agriculture 2019, 5, 1, https://doi.org/10.1080/23311932.2019.1641255.

42. Ahmed, A.A. Sensory quality of smoked Clarias gariepinus (Burchell, 1822) as affected by spices packaging methods, Journal International Journal of Food Properties 2019, 22(1), 704-713. 
43. Sowunmi, A.A. Fin-fishes in Yorùbá natural healing practices from southwest Nigeria. Journal of Ethnopharmacology 2007, 113, 72-78, https://doi.org/10.1016/j.jep.2007.05.011.

44. Udupa, K.S.Identification of impact attribute in food products. In: The First Indian Fisheries Forum. Proceedings. Asian Fisheries Society, Indian Branch, Mangalore, 1988; pp. 451-453.

45. Sikoki, F.D.; Aminigo, E.R.Bacteriological and sensory properties of smoke-dried fishstoredatambienttemperature.Global Journal of Agricultural Sciences 2002, 1, 21-25.

46. Osibona, A.O.; Ogunyebi, O.O; Samuel, T.O; Storage Fungi and Mycotoxins Associated with Stored Smoked Catfish (Clarias gariepinus). Journal of Applied Sciences and Environmental Management, 2019, 22, 643-646. 